\title{
The Lizzie Hill Site (41CP494), Camp County, Texas
}

Timothy K. Perttula

Heritage Research Center, Stephen F. Austin State University

Follow this and additional works at: https://scholarworks.sfasu.edu/ita

Part of the American Material Culture Commons, Archaeological Anthropology Commons, Environmental Studies Commons, Other American Studies Commons, Other Arts and Humanities Commons, Other History of Art, Architecture, and Archaeology Commons, and the United States History Commons

Tell us how this article helped you.

This Article is brought to you for free and open access by the Center for Regional Heritage Research at SFA ScholarWorks. It has been accepted for inclusion in Index of Texas Archaeology: Open Access Gray Literature from the Lone Star State by an authorized editor of SFA ScholarWorks. For more information, please contact cdsscholarworks@sfasu.edu. 


\section{The Lizzie Hill Site (41CP494), Camp County, Texas}

Creative Commons License

(c) (i) (8)

This work is licensed under a Creative Commons Attribution-NonCommercial 4.0 International License 


\title{
The Lizzie Hill Site (41CP494), Camp County, Texas
}

\author{
Timothy K. Perttula
}

\section{INTRODUCTION AND SETTING}

The Lizzie Hill site (41CP494) is one of a number of archaeological sites that Robert L. Turner, Jr. surface collected from in Camp County, Texas in the 1950s and 1960s. Bo Nelson and Turner formally recorded the site in July 2012. The analysis of the surface collection of ceramic and lithic artifacts from the site, as well as a few historic artifacts, is the subject of this article.

The site was located in a cultivated field when Turner found it and gathered his collection of artifacts, but now is in pasture, along a small tributary to Walkers Creek in the Big Cypress Creek basin. The site is estimated to cover a ca. $160 \times 80 \mathrm{~m}$ area (ca. 3 acres) on an upland slope (360-380 ft. amsl).

\section{ARTIFACT COLLECTIONS}

\section{Ceramic Artifacts}

A small sample of ancestral Caddo ceramic vessel sherds $(n=29)$ are in the Lizzie Hill site collections gathered by Robert L. Turner, Jr. These include plain wares (Figure 1d), utility wares (decorated with wet paste designs - incised, punctated, brushed, etc.), and fine wares (decorated after the vessel was leather hard or had been fired). The ceramic sherds are from vessels made primarily with a grog (i.e., crushed sherd) temper, but $10.3 \%$ of the sherds, both plain body sherds, are from bone-tempered vessels (Table 1).

Table 1. Use of bone as a temper in the Horton site sherd assemblage.

\begin{tabular}{lllll}
\hline Ware & Rim & body & base & N \\
\hline Plain & $0 / 1$ & $3 / 17$ & $0 / 4$ & $3 / 22$ \\
Utility & - & $0 / 5$ & - & $0 / 5$ \\
Fine & - & $0 / 2$ & - & $0 / 2$ \\
\hline Totals & $0 / 1$ & $3 / 24$ & $0 / 4$ & $3 / 29$ \\
\hline
\end{tabular}

Two of the utility ware sherds are body sherds with parallel (Figure 1c) or opposed brushing marks. The brushed sherds suggests that the Caddo sherds are from an occupation that occurred after ca. A.D. 1250. One other utility ware body sherd has parallel incised lines (Figure 1b). Two other body sherds have a row of tool punctates above or below horizontal incised lines (Figure 1e-f). The first fine ware sherd is a body sherd with parallel engraved lines, while the other has a red slip on its exterior surface (Figure 1a).

\section{Lithic Artifacts}

An extensive collection of chipped stone tools and debris and ground stone tools comprises the lithic artifact assemblage from the Lizzie Hill site. This includes among the chipped stone: arrow points $(n=4)$, 

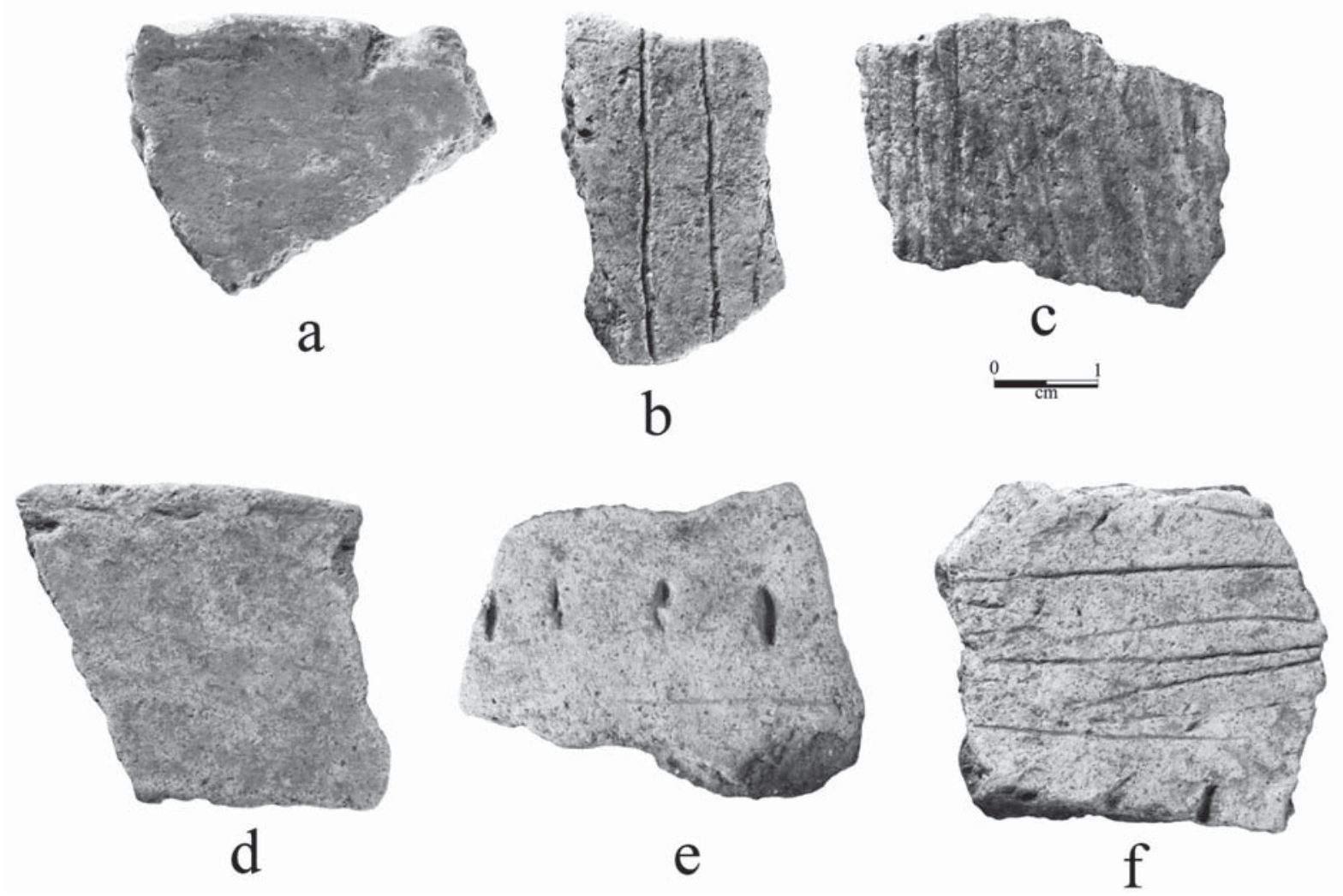

Figure 1. Decorated sherds and plain rim sherd from the Lizzie Hill site: a, red-slipped body sherd; b, incised body sherd; c, brushed body sherd; d, plain rim; e-f, incised-punctated body sherds.

many dart points $(n=366)$ and bifaces $(n=151)$, gouges $(n=13)$, flake tools $(n=31)$, cores $(n=40)$, a hematite axe fragment, and a few pieces of lithic debris. Ground stone tools $(n=14)$ includes manos, pitted stones, and grinding slabs.

\section{Chipped Stone}

\section{Arrow Points}

Arrow points are rare in the Lizzie Hill site collection. All four points, unidentified to type, are made from local quartzite (Figure 2a-d). Two have contracting stems, a third has a straight stem, and the last is corner-notched, with an expanding stem.

\section{Dart Points}

There is a large collection of dart points and point fragments from the Lizzie Hill site (Table 2). A total of 287 dart points have been identified to specific types (cf. Turner et al. 2011); another 16 fragmentary dart points can only be categorized by stem form or the form of notching. Almost all of the dart points are from the Late Archaic (ca. 5000-2500 years B.P.) and Woodland (ca. 2500-1200 years B.P.) use of the site by aboriginal peoples. Of the 287 typologically identified projectile points in the Lizzie Hill collection, $0.7 \%$ are Late Paleoindian forms, 3.5\% are Middle Archaic forms; 34\% are Late Archaic dart point types, and the remaining $62 \%$ are Woodland period dart points. 

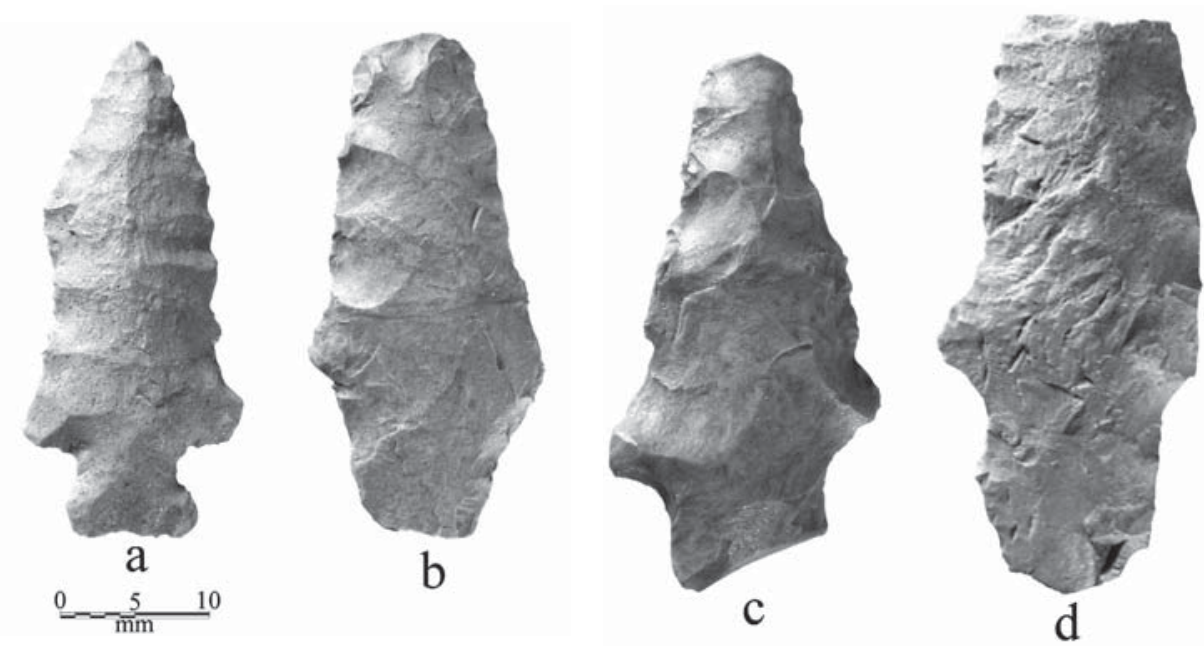

Figure 2. Arrow points from the Lizzie Hill site.

Table 2. Dart points from the Lizzie Hill site.

\begin{tabular}{|c|c|c|c|c|c|c|c|}
\hline \multirow[t]{2}{*}{ Type or Form } & \multicolumn{5}{|c|}{ Lithic Raw Material } & \multirow[b]{2}{*}{$\%$} & \multirow[b]{2}{*}{$\mathrm{N}$} \\
\hline & 1 & 2 & 3 & 4 & 5 & & \\
\hline Bulverde & - & - & - & - & 1 & & 1 \\
\hline Calf Creek & - & - & - & - & 2 & & 2 \\
\hline Carrollton & 2 & - & - & - & - & & 2 \\
\hline cf. Dalton & 1 & - & - & - & - & & 1 \\
\hline Delhi & - & 1 & - & - & 2 & & 3 \\
\hline Edgewood & 12 & - & - & - & 3 & & 15 \\
\hline Ellis & 4 & - & 3 & - & 2 & & 9 \\
\hline Gary, narrow & 42 & 1 & 1 & 6 & - & & 50 \\
\hline Gary, wide & 91 & - & 8 & 1 & 4 & & 104 \\
\hline Gary, preform & 13 & - & - & - & - & & 13 \\
\hline Godley & 3 & - & - & - & - & & 3 \\
\hline Kent & 6 & 1 & - & 1 & - & & 8 \\
\hline Morrill & 6 & - & - & - & 1 & & 7 \\
\hline Neches & 1 & - & - & - & - & & 1 \\
\hline cf. Scottsbluff & - & - & - & - & 1 & & 1 \\
\hline Trinity & 2 & - & - & - & - & & 2 \\
\hline Wells & 6 & - & - & - & - & & 6 \\
\hline White River & - & - & - & - & 1 & & 1 \\
\hline Williams & 2 & - & - & - & 1 & & 3 \\
\hline Yantis & 5 & - & - & - & - & & 5 \\
\hline Yarbrough & 47 & - & - & 1 & 2 & & 50 \\
\hline UID expanding stem & 2 & - & - & - & 1 & & 3 \\
\hline UID side-notched & - & - & - & - & 2 & & 2 \\
\hline $\begin{array}{l}\text { UID narrow-straight } \\
\text { stem }\end{array}$ & 4 & - & - & - & 1 & & 5 \\
\hline UID straight stem & 3 & - & - & 1 & 2 & & 6 \\
\hline Dart point fragments & 51 & - & 1 & 4 & 7 & & 63 \\
\hline Totals & 303 & 3 & 13 & 14 & 33 & & 366 \\
\hline
\end{tabular}

UID=unidentified; $1=$ local quartzite; $2=$ petrified wood; $3=$ local chert; $4=$ novaculite; 5 -non-local chert 
Approximately $87 \%$ of the dart points at the site are made from local raw materials, including quartzite $(83 \%)$, petrified wood $(0.8 \%)$, and local cherts $(3.5 \%)$. The remainder are either made from Ouachita Mountains novaculite $(3.8 \%$ ) or various Ouachita Mountains or Central Texas source area cherts $(9 \%$ ) (see Table 2). There are differences through time in the use of non-local lithic raw materials in the dart point assemblages. Not including Late Paleoindian types in the collection, point types made predominantly from non-local lithic raw materials include Bulverde, Calf Creek, Delhi, and unidentified side notched forms, dating from Middle to Late Archaic times. Dart point types particularly made from local raw materials include Carrollton (100\%), Wells (100\%), Yantis (100\%, see Johnson 1962:171-173), Gary, wide (95\%), Yarbrough (94\%), Gary, narrow (88\%), and Kent (88\%) types (see Table 2), dart point types made during the Late Archaic and Woodland periods.

There are a few dart points in the Lizzie Hill dart point assemblage that are types that predate the Late Archaic. These include Late Paleoindian Dalton and Scottsbluff points (Figure 3c-d), extensively resharpened Middle Archaic side-notched forms (Figure 3a-b), one White River side-notched point that may date from 5200-4500 B.C. (e.g., Trubitt 2009:79), and Middle Archaic Calf Creek points (Figure 3e). With the exception of the Dalton point, made from a local quartzite, the other points from these early contexts are on non-local cherts, probably from Central Texas Edwards Formation cherts.

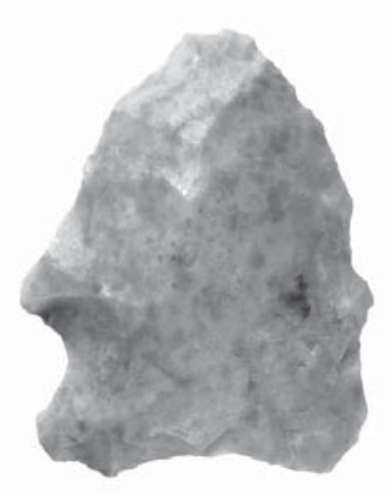

a

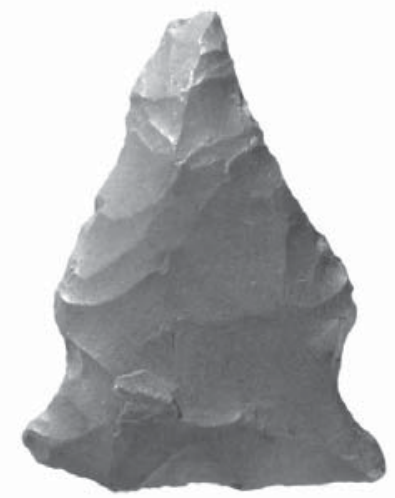

b

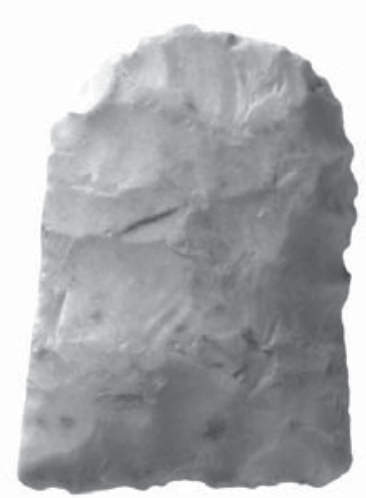

$\mathrm{C}$
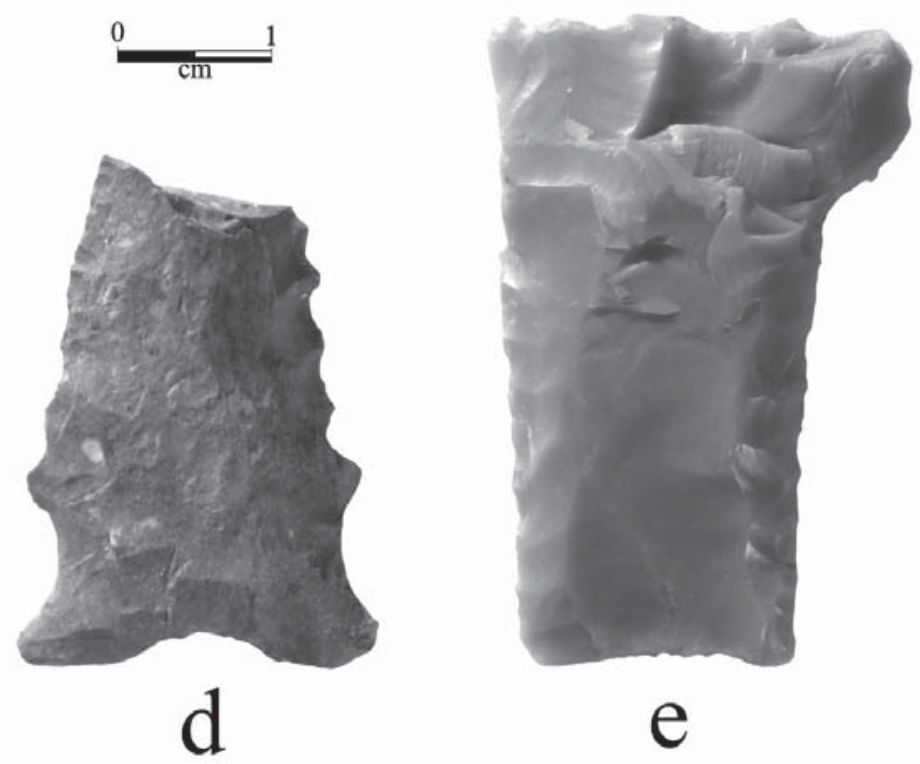

Figure 3. Early forms (Late Paleoindian-Middle Archaic) of dart points from the Lizzie Hill site: a-b, sidenotched; c, cf. Scottsbluff; d, cf. Dalton; e, Calf Creek. 
Turner et al. (2011:139) consider the Morrill type to be a Middle Archaic point form. Those from the Lizzie Hill site (Figure 4a-e) are made primarily from local quartzite, although one is on a non-local chert (Figure 4d).

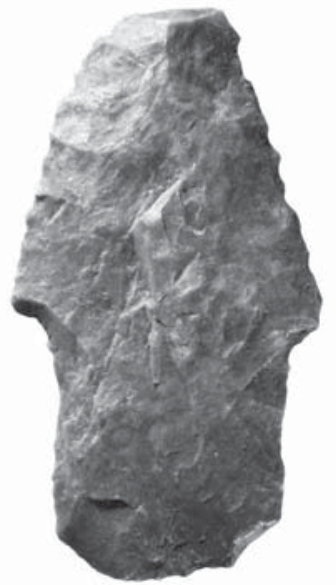

a
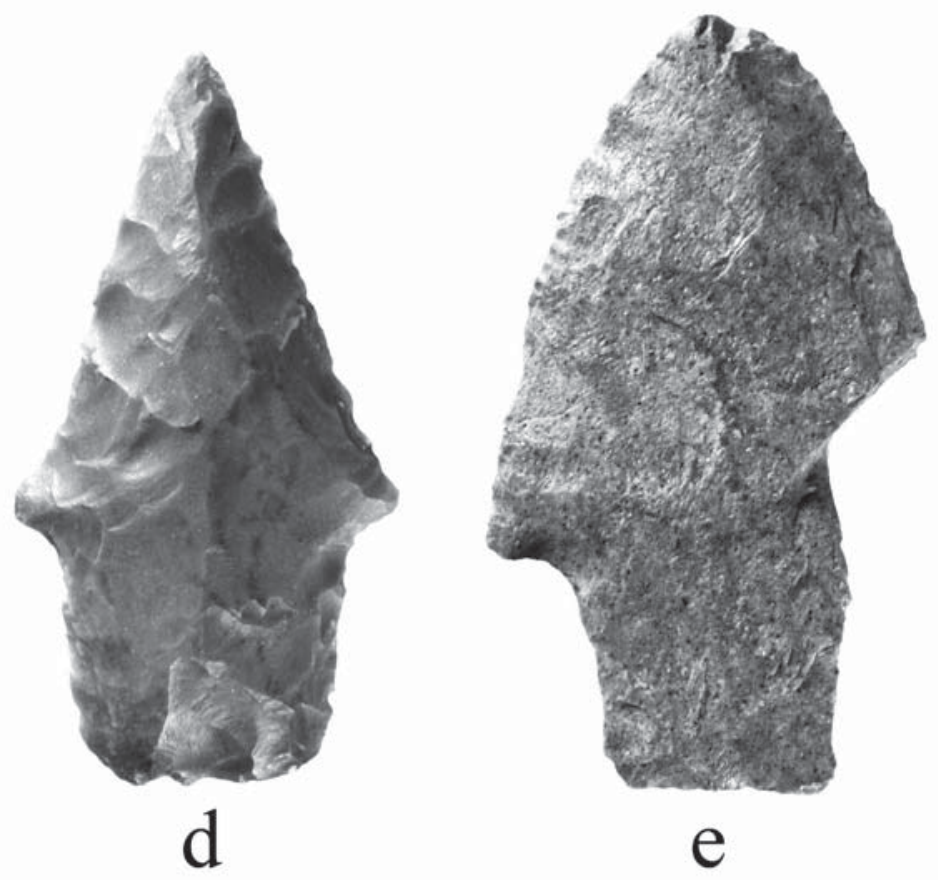

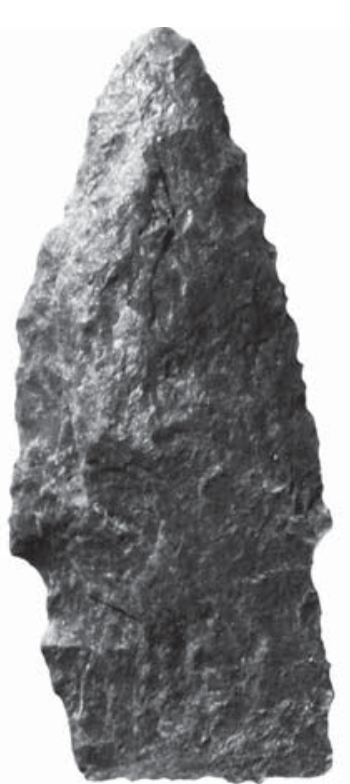

C

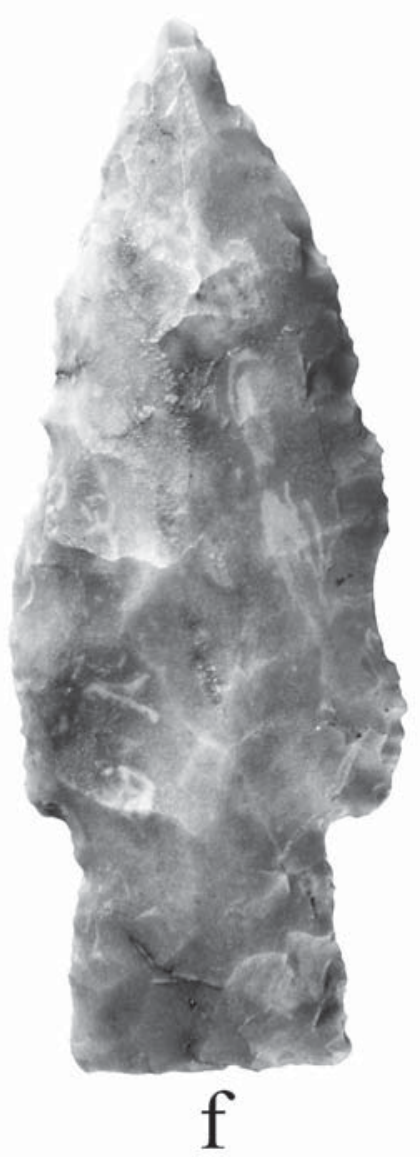

Figure 4. Morrill and Delhi points: a-e, Morrill; f, Delhi. 
The wide variety of Late Archaic projectile points in the Lizzie Hill dart point assemblage include the following types and stemmed forms: Bulverde, Carrollton, Delhi (see Figure 4f), Neches, Trinity, Wells (Figure 5), Yantis, Yarbrough (Figure 6), Williams (Figure 7), a distinctive narrow-stemmed form that may be extensively resharpened Wells points (Figure 8), Edgewood (Figure 9), and Ellis (Figure 10). By far the most common Late Archaic dart point type at the site is the Yarbrough, which represents approximately 50\% of the Late Archaic dart point assemblage, following by the Edgewood and Ellis types.
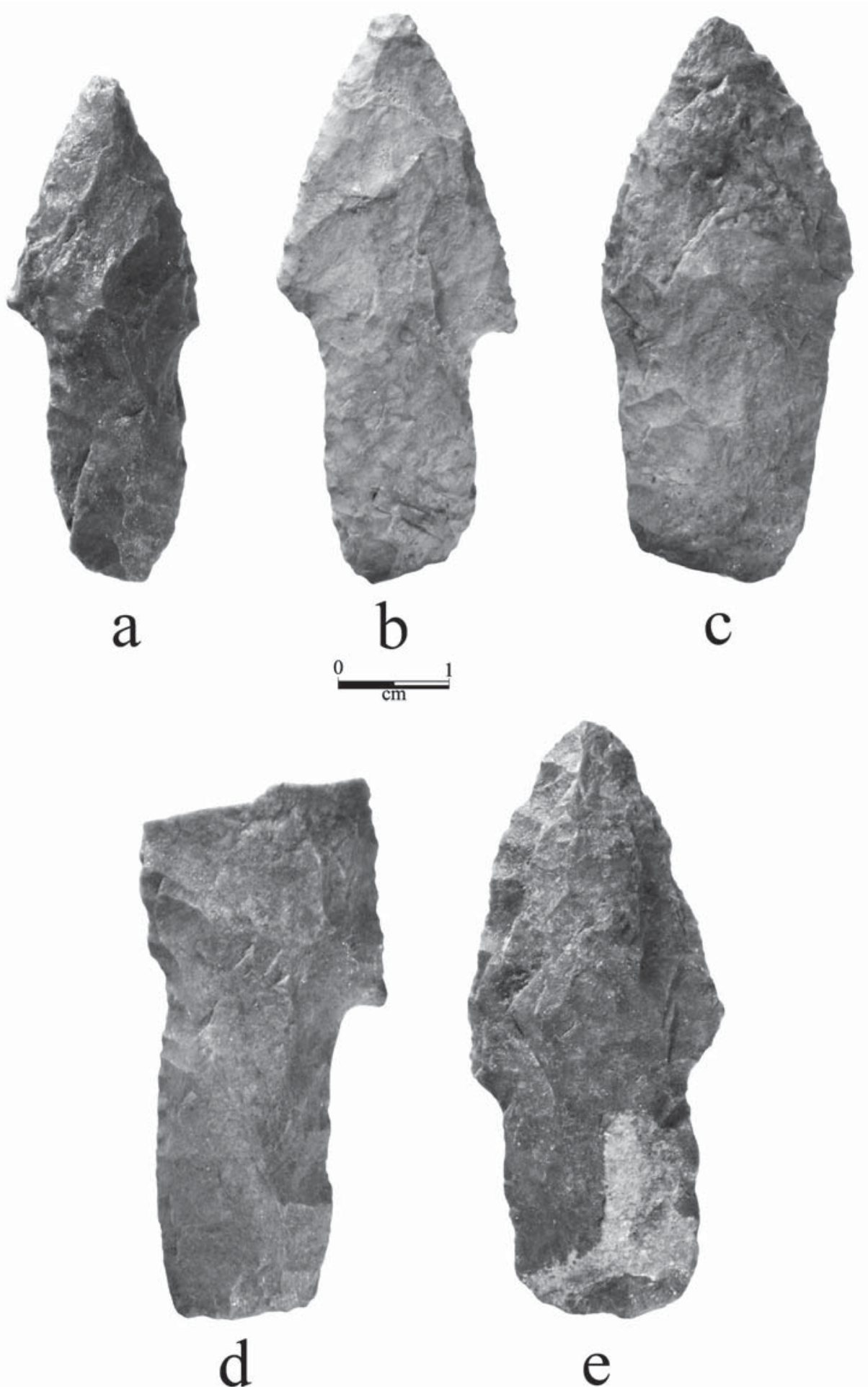

Figure 5. Wells dart points from the Lizzie Hill site. 


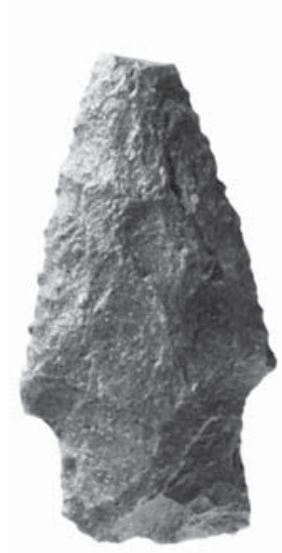

a

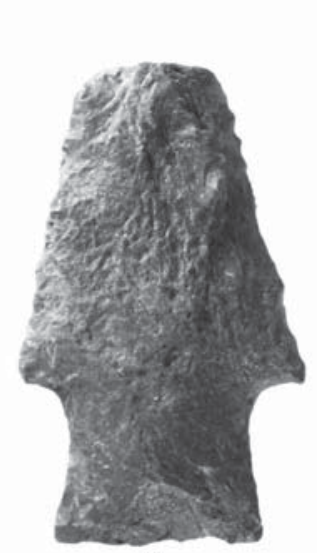

b

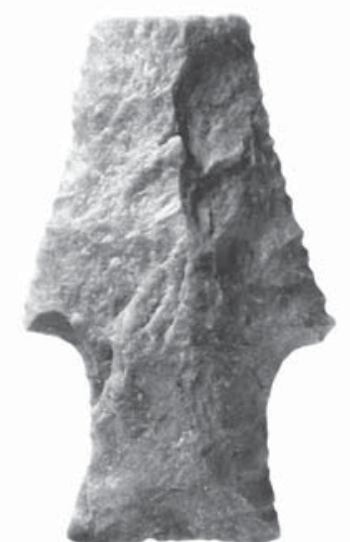

$\mathrm{C}$

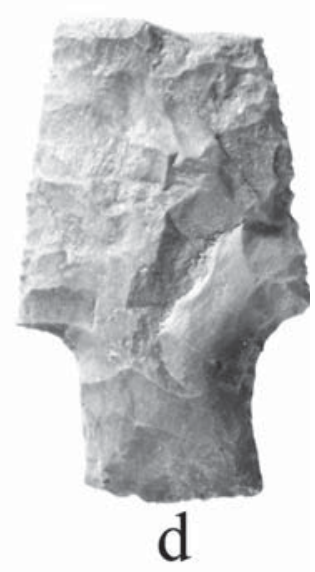

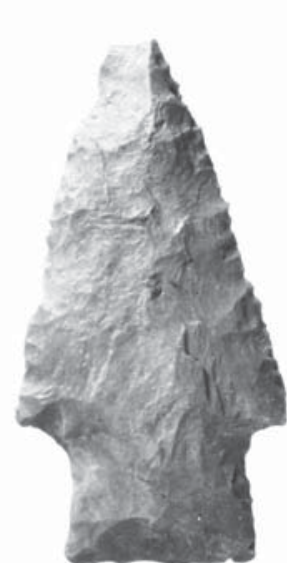

e

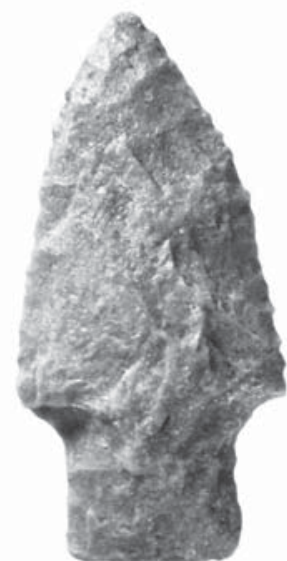

$\mathrm{f}$

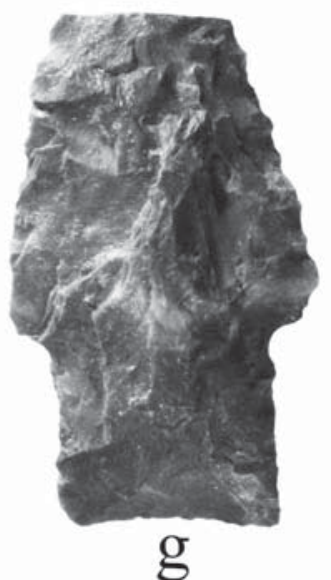

Figure 6. Yarbrough dart points from the Lizzie Hill site.

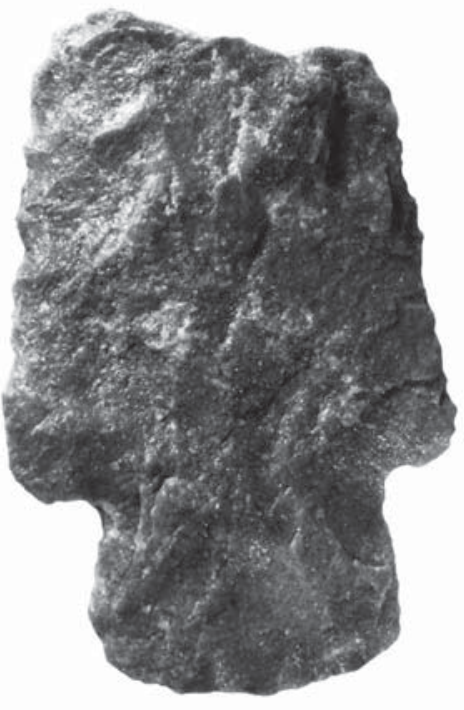

a
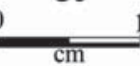

Figure 7. Williams dart points from the Lizzie Hill site

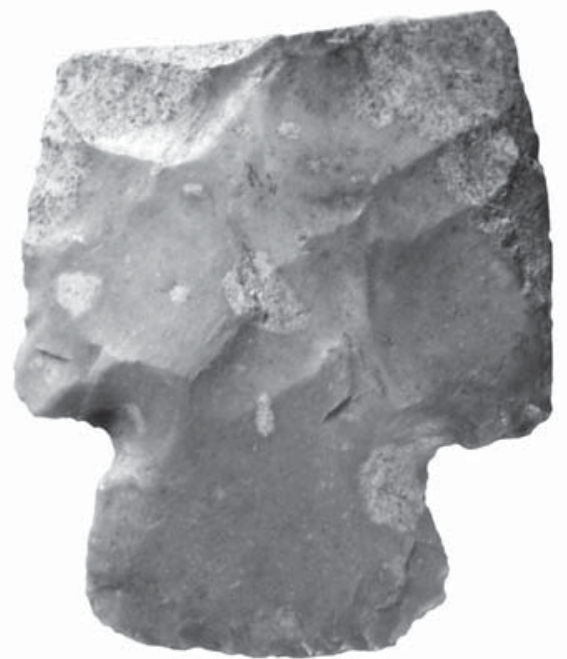

b 


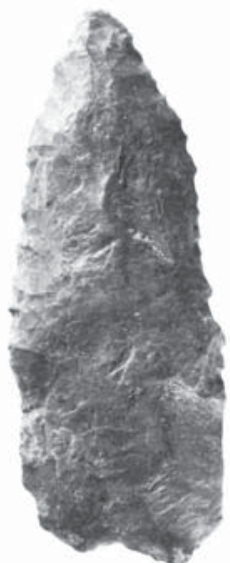

a

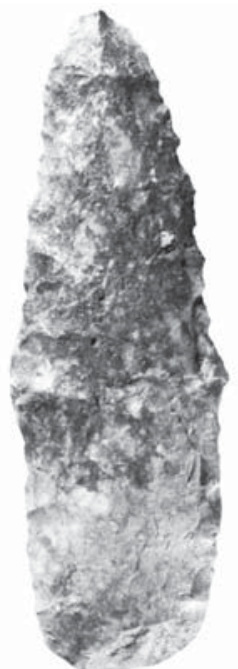

b

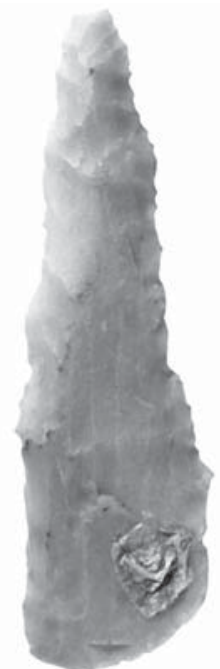

C

Figure 8. Narrow-stemmed dart points from the Lizzie Hill site.

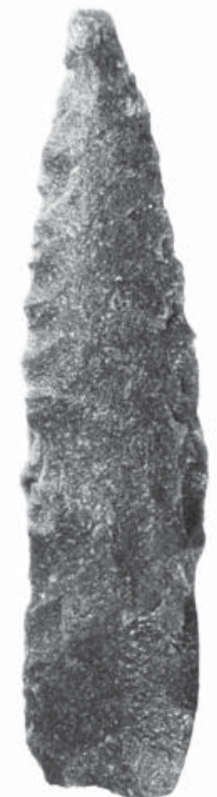

d

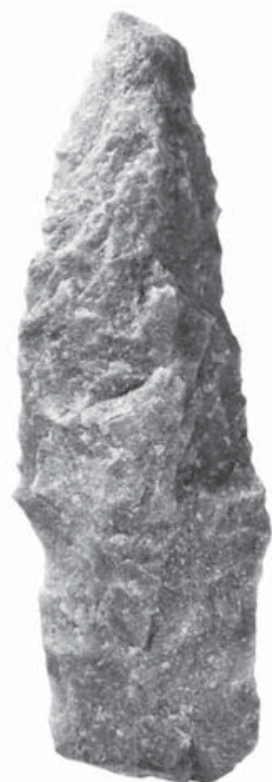

e

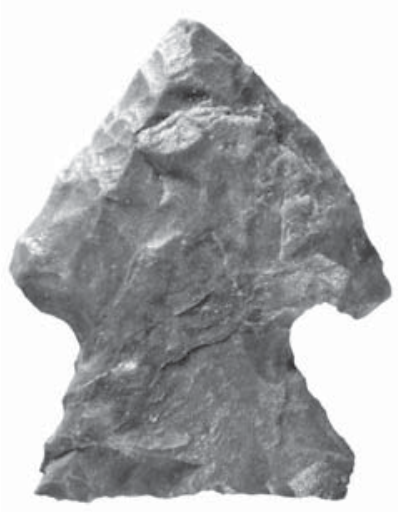

a

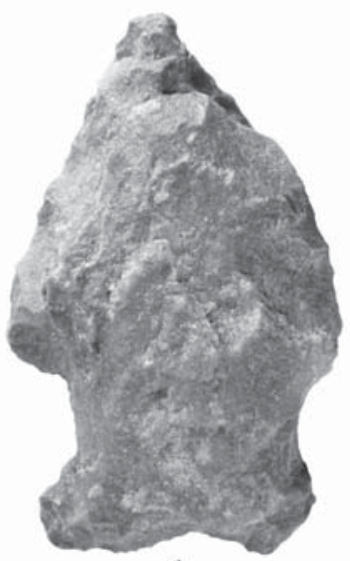

b
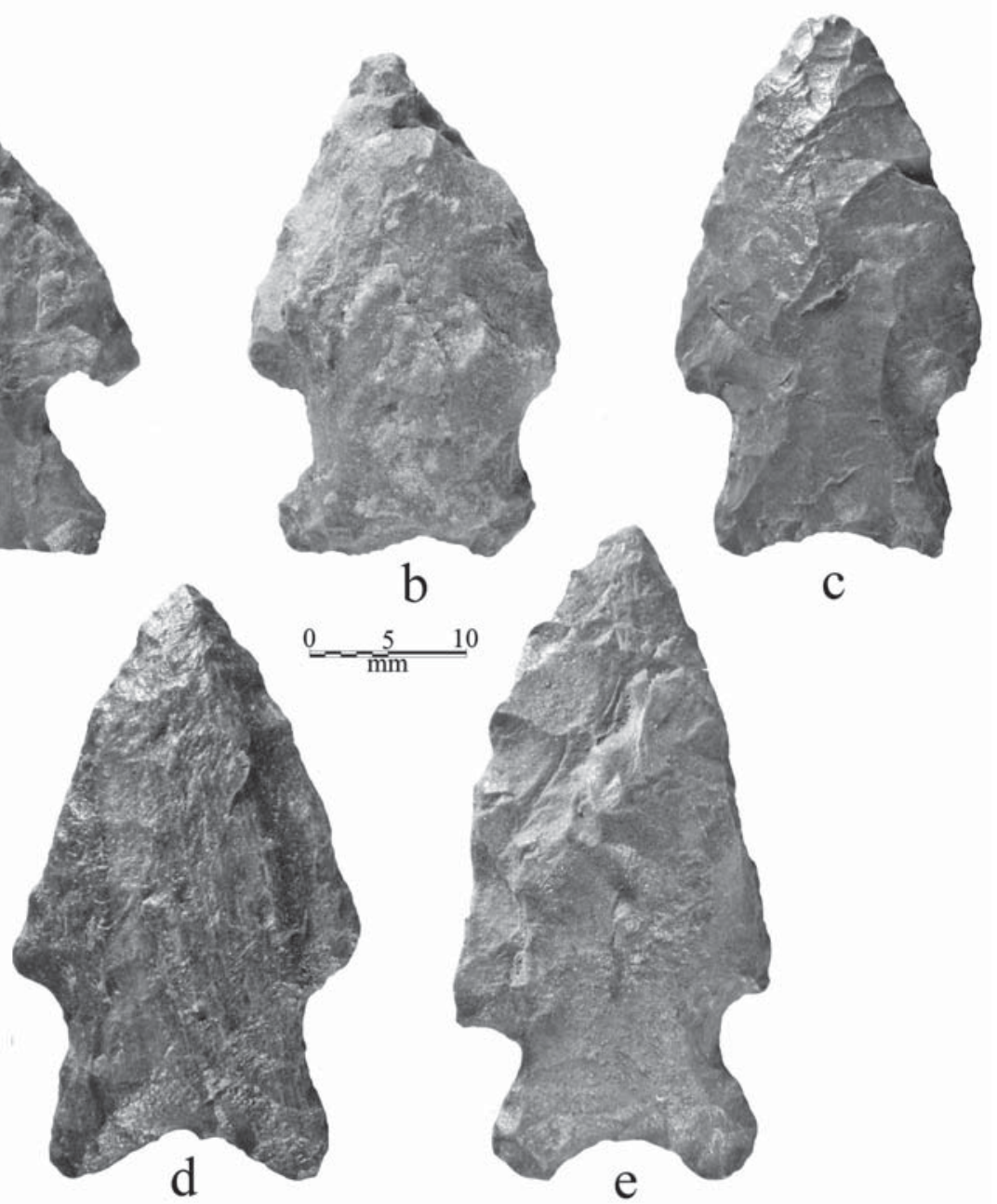

Figure 9. Edgewood dart points from the Lizzie Hill site. 
Late Archaic dart points are overwhelmingly made from local lithic raw materials: $88 \%$ are made from local quartzite $(95 \%)$ and petrified wood $(5 \%)$. The points made from non-local lithic raw materials include non-local cherts (92\% of the points made from non-local raw materials) and novaculite ( $8 \%$ of the points made from non-local lithics, namely one Yarbrough point).

The Woodland period dart points $(\mathrm{n}=178)$ include Kent $(4.4 \%)$, wide and narrow Gary points $(94 \%)$, and Godley (1.7\%) types (Figures 11-13). Earlier and later Gary points (i.e., the width of Gary points is thought to decrease through the period, see Schambach $[1982,1998]$, with the thinnest and narrowest Gary points occurring in the latter part of the Woodland period) are clearly the principal Woodland period point form at the Lizzie Hill site.

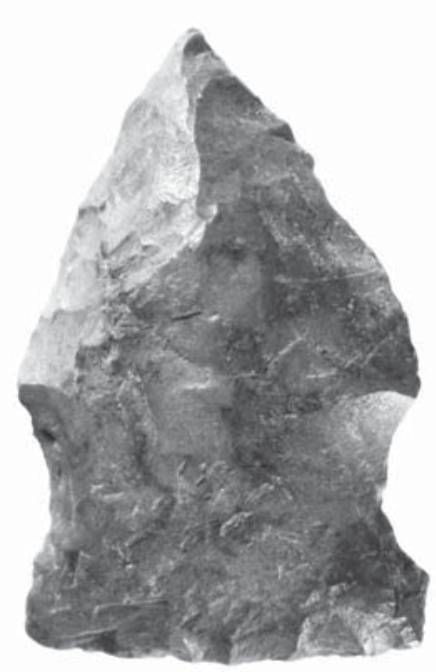

a

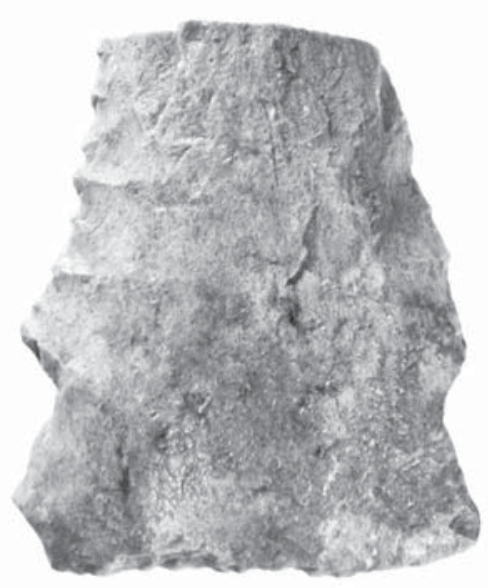

b

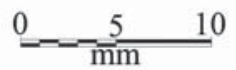

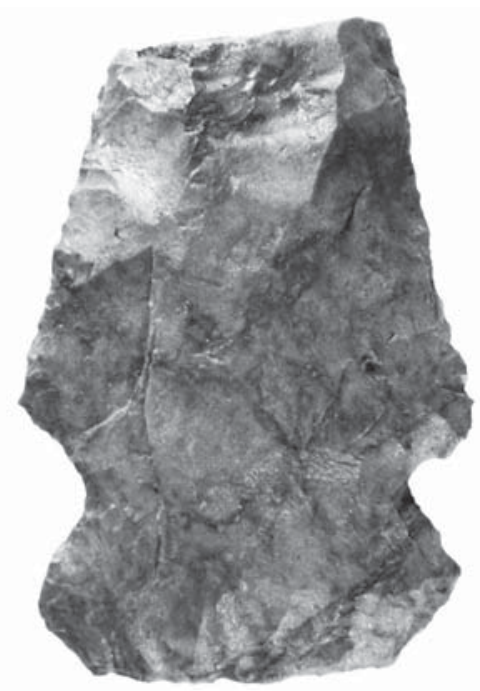

c

Figure 10. Ellis dart points from the Lizzie Hill site.

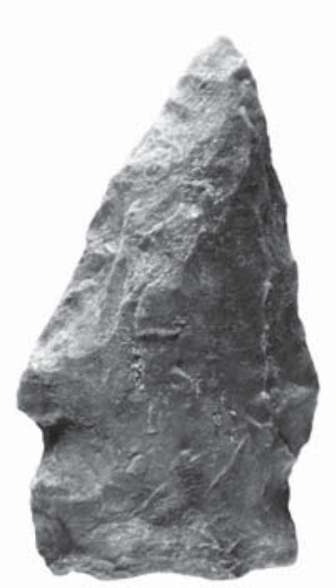

a

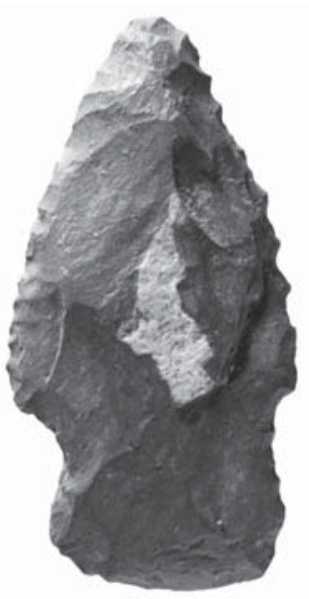

b

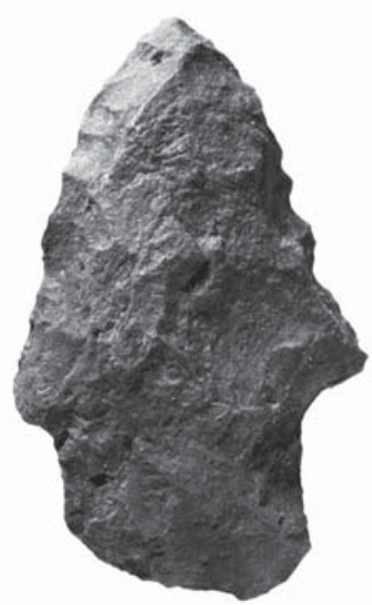

c

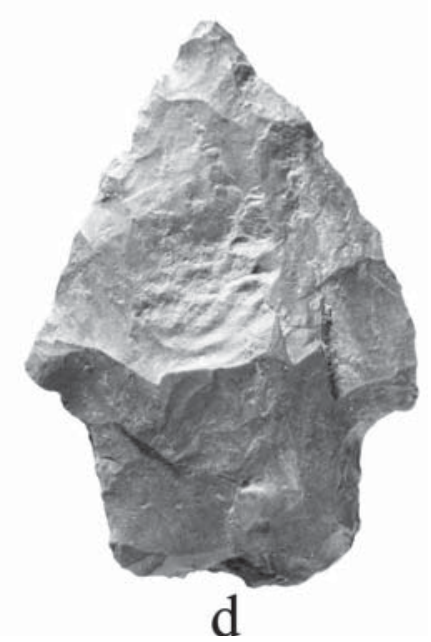

Figure 11. Kent dart points from the Lizzie Hill site. 


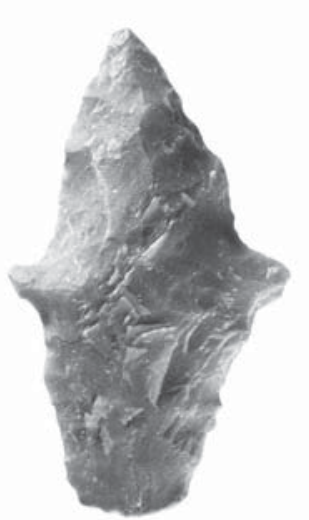

a

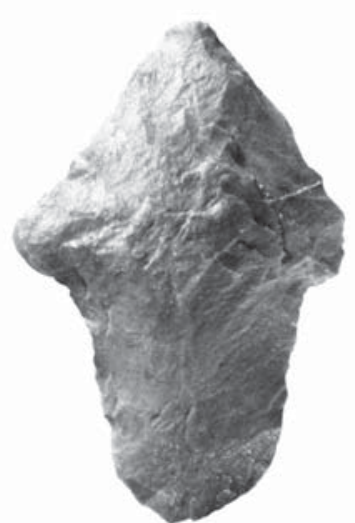

b

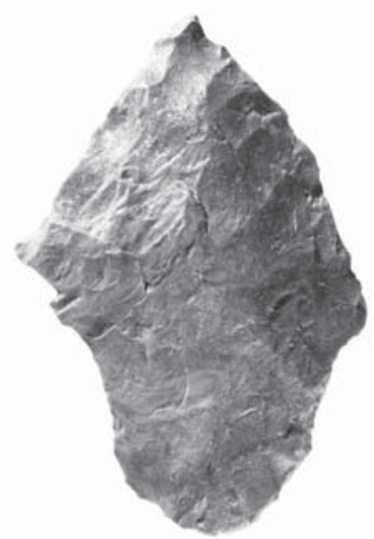

C

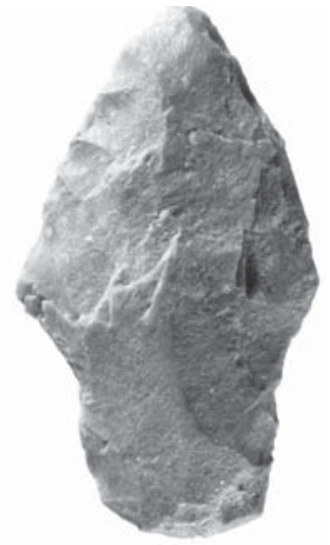

d

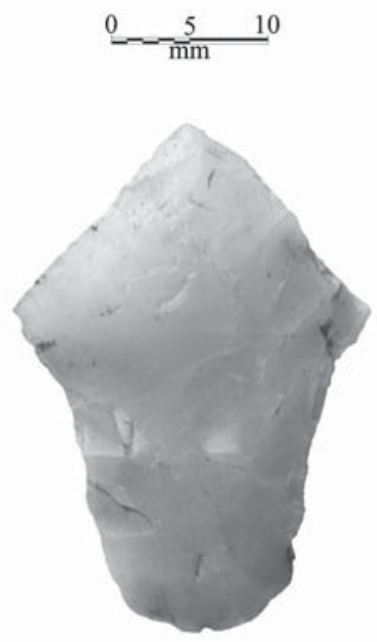

e
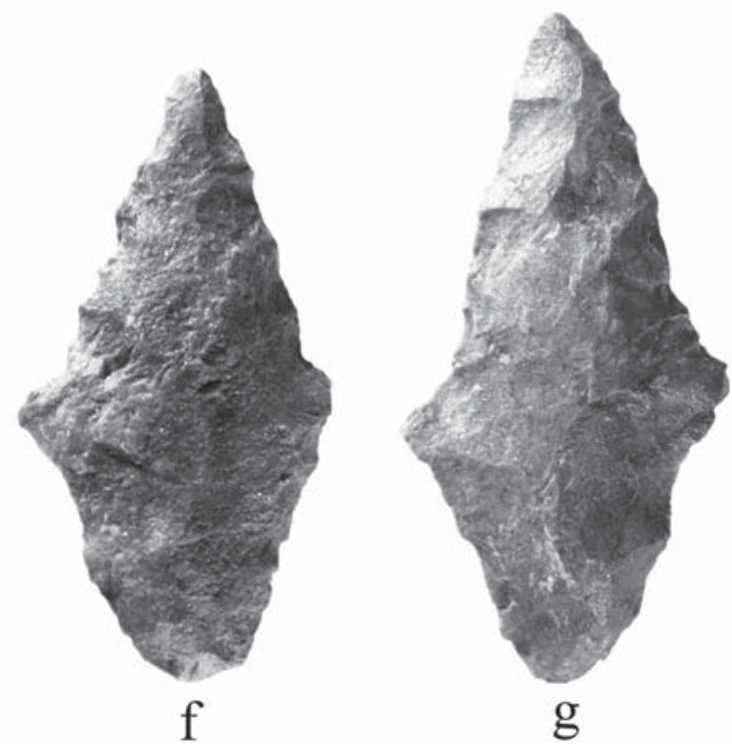

Figure 12. Gary, wide, dart points from the Lizzie Hill site.

Woodland period dart points from the Lizzie Hill site are also made almost exclusively of local lithic raw materials (93\%), especially quartzite. Only a few Woodland period dart points on local lithic raw materials are made from petrified wood $(1.2 \%)$ or chert $(5.4 \%)$. The Woodland period dart points on non-local lithic raw materials $(\mathrm{n}=12$, or $6.8 \%$ of the total Woodland period dart point sample) are on both novaculite (67\% of the points made from non-local lithic raw materials) and chert (33\%). The increased use of novaculite from Late Archaic to Woodland period times is notable in the Lizzie Hill dart point assemblage.

\section{Bifaces}

Bifaces and bifacial tools (non-projectile points) are common in the Lizzie Hill lithic assemblage (Table 3 ). They include fragments discarded at various stages during the manufacturing process (88\%), particularly early stage bifaces, as well as broken bifacial tools and knive fragments (12\% of the bifaces). The discarded bifacial manufacturing failures are made almost exclusively (97.8\%) from local lithic raw materials, principally quartzite, suggesting these are the product of on-site manufacturing activities, but three preforms are made from Ouachita Mountains novaculite (see Table 3). Bifacial tools and knives, on the other hand, at the Lizzie Hill site are regularly made (50\%) from non-local Ouachita Mountains and Central Texas cherts, and were likely imported into the site from these areas. 

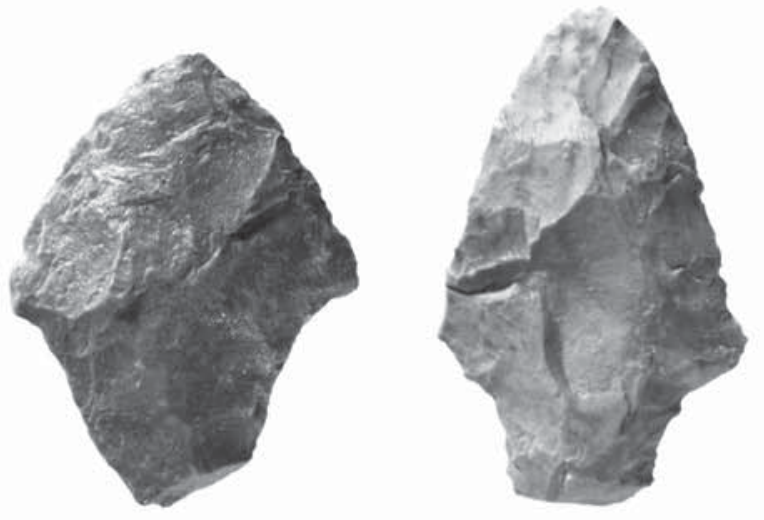

a

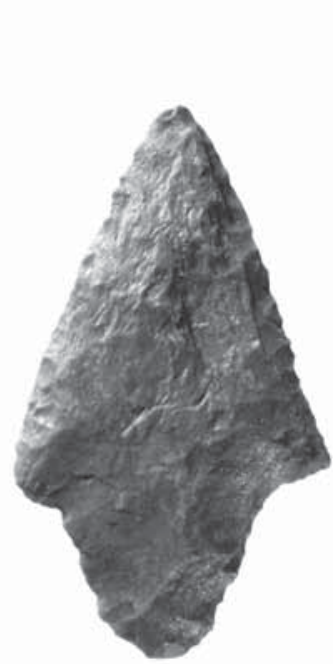

d b

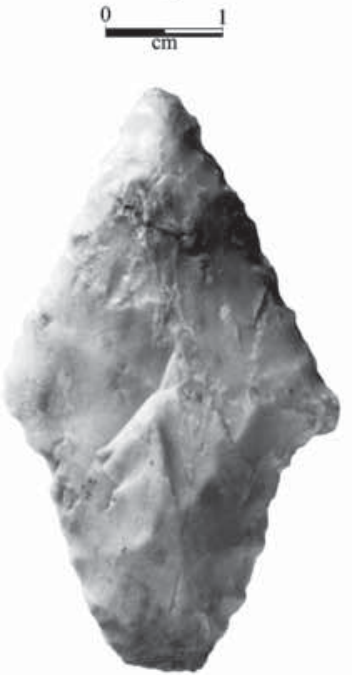

e

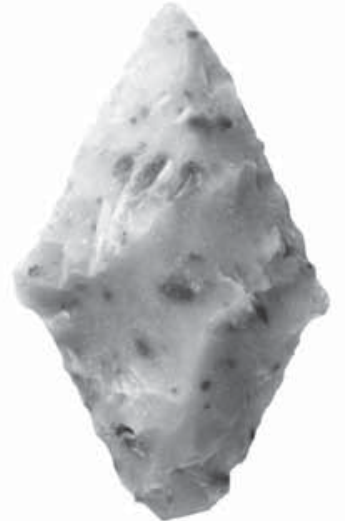

C

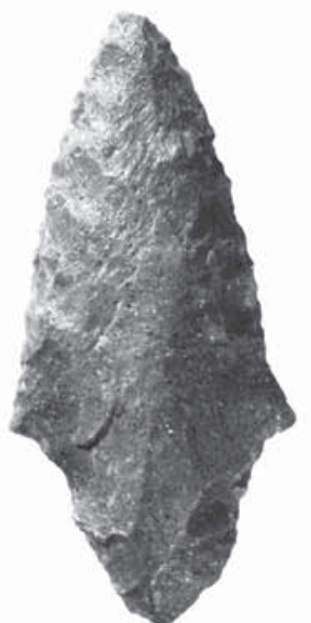

f

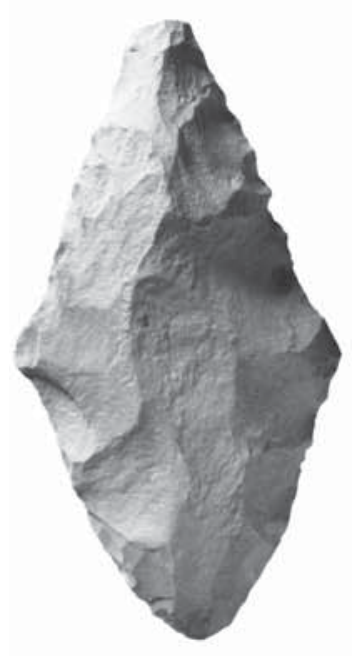

$\mathrm{g}$

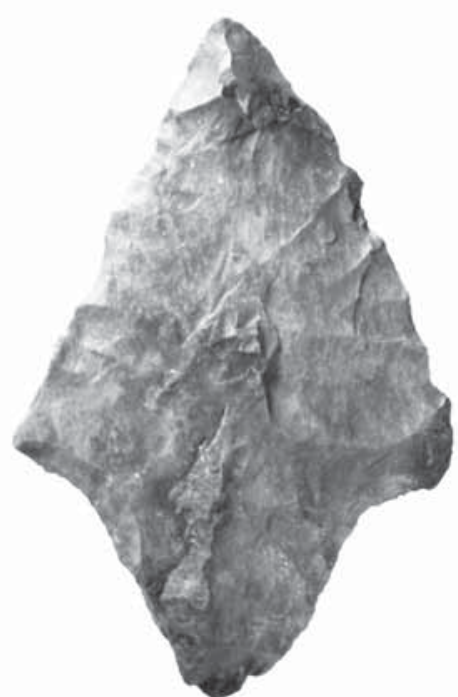

$\mathrm{h}$

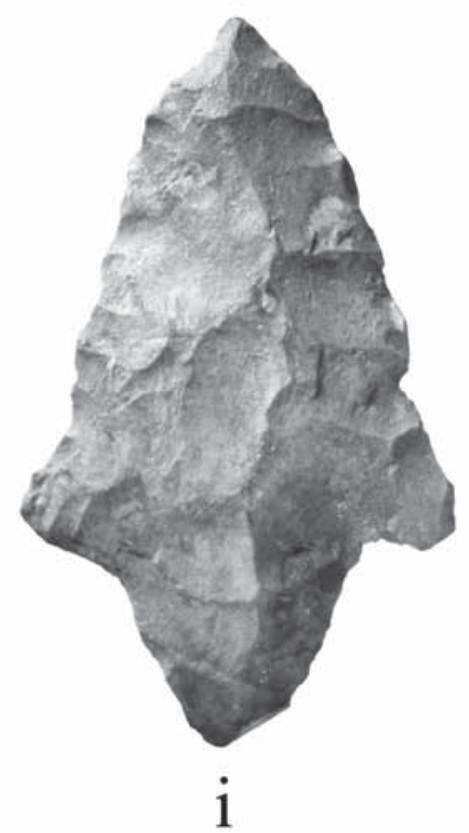

Figure 13. Gary, narrow dart points from the Lizzie Hill site. 
Table 3. Bifaces from the Lizzie Hill site.

\begin{tabular}{llllllll}
\hline \multirow{2}{*}{ Type or Form } & \multicolumn{7}{c}{ Lithic Raw Material } \\
& 1 & 2 & 3 & 4 & 5 & $\%$ & $\mathrm{~N}$ \\
\hline early stage & 80 & 1 & 3 & 2 & - & 57.0 & 86 \\
late stage & 16 & - & - & - & - & 10.6 & 16 \\
preform & $32 *$ & 1 & 1 & 1 & - & 23.2 & 35 \\
$\begin{array}{l}\text { Bifacial tool/tool } \\
\text { fragment }\end{array}$ & 9 & - & - & - & 8 & 11.3 & 17 \\
knife & - & - & - & - & 1 & 0.7 & 1 \\
\hline Totals & 137 & 2 & 4 & 3 & 9 & 100.0 & 151 \\
\hline
\end{tabular}

1=local quartzite; $2=$ petrified wood; $3=$ local chert; 4=novaculite; 5 -non-local chert *includes two ferruginous sandstone

Several of the bifacial tools are bifacially flaked quartzite tools with either lateral (Figure 14c-d) or lateral/end (Figure 14a-b, e) retouch and use-worn areas. These are probably small hand-held adzes or wedges. Finally, there is a large ferruginous sandstone biface preform in the collection (see Figure 16e).

Bifacial tool and knive fragments comprise $12 \%$ of the bifaces from the Lizzie Hill site. These are percussion and pressure-flaked pieces with generally broad blades and symmetrical edges with evidence of retouch/use-wear (Figure 15a-d). Half of these tools are made from local raw materials, and half made from non-local cherts (see Table 3).

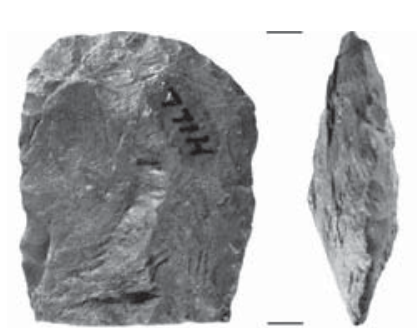

a
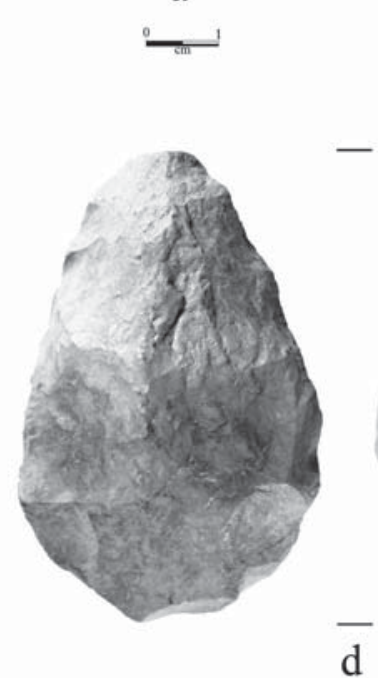
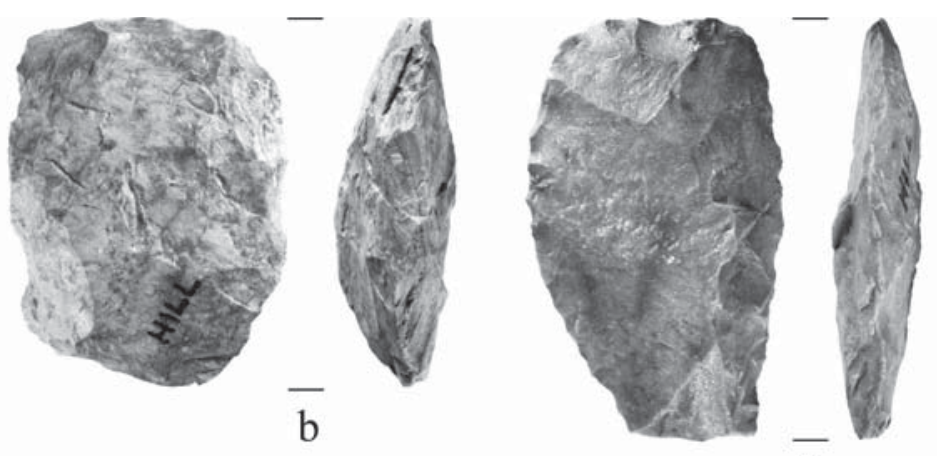

$\overline{\mathrm{c}}$

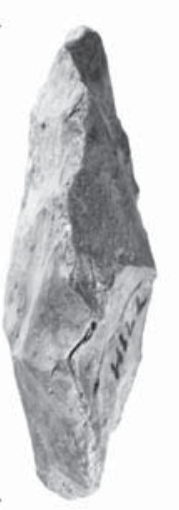

d

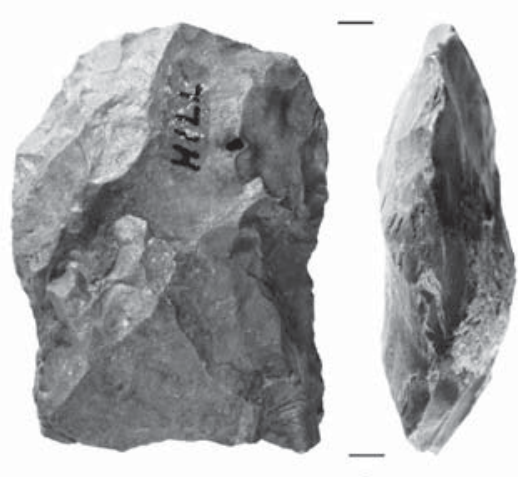

$\mathrm{e}$

Figure 14. Quartzite bifacial tools from the Lizzie Hill site. 


\section{Gouges}

Middle to Late Archaic period gouges (cf. Turner 2006:Figure 20) are common at the Lizzie Hill site (Table 4). The 13 gouges include five with one polished surface (Figure 16d) opposite the tool bit and eight without a polished surface (Figure 16a-c).

Table 4. Chipped stone gouges from the Lizzie Hill site.

\begin{tabular}{lccccccc}
\hline \multirow{2}{*}{ Tool Type } & \multicolumn{7}{c}{ Lithic Raw Material } \\
& 1 & 2 & 3 & 4 & 5 & $\mathrm{~N}$ & $\%$ \\
\hline Gouge with polished surface & - & - & 1 & 3 & 1 & 5 & 38.5 \\
Gouge without polished surface & 4 & 1 & - & 3 & - & 8 & 61.5 \\
\hline Totals & 4 & 1 & 1 & 6 & 1 & 13 & 100.0 \\
\hline
\end{tabular}

1=local quartzite; $2=$ petrified wood; 3 ; local chert; 4=ferruginous sandstone; $5=$ hematite

The gouges are made from a variety of local lithic raw materials, primarily ferruginous sandstone (46\%, see Figure 16c) and quartzite (31\%, see Figure 16a), with single examples of tools made from petrified wood (see Figure 16b), a local chert, and hematite (see Figure 16d).
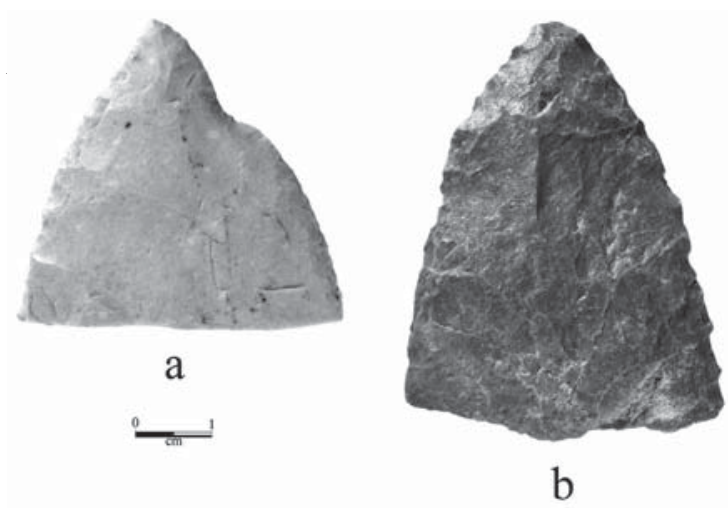

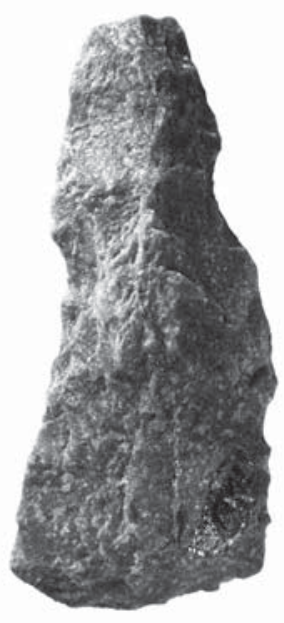

c

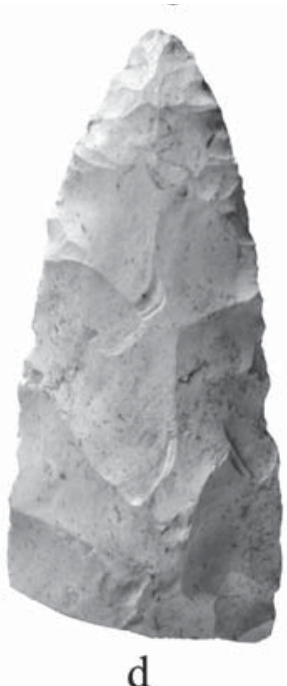

d

Figure 15. Bifacial tool fragments: a-c, bifacial tool fragments; d, bifacial knive fragment.

There is a diverse range of flake tools in the Lizzie Hill lithic assemblage, including expedient flake tools used on one or more flake edges, an expedient flake tool with a graver tip, scrapers, and a drill (Table 5). The most common tools are unilateral use-worn/retouched flake tools (Figure 17d, f-h) and side scrapers (Figures $17 \mathrm{c}$ and $18 \mathrm{a}-\mathrm{b}$ ); these comprise $77.4 \%$ of the flake tools. 
Table 5. Flake tools from the Lizzie Hill site.

\begin{tabular}{|c|c|c|c|c|c|c|c|}
\hline \multirow[t]{2}{*}{ Tool Type } & \multicolumn{5}{|c|}{ Lithic Raw Material } & \multirow[b]{2}{*}{$\mathrm{N}$} & \multirow[b]{2}{*}{$\%$} \\
\hline & 1 & 2 & 3 & 4 & 5 & & \\
\hline unilateral use-worn edges & 3 & 1 & - & 2 & 13 & 19 & 61.3 \\
\hline bilateral use-worn edges & - & - & - & - & 2 & 2 & 6.4 \\
\hline bilateral and graver & - & - & - & - & 1 & 1 & 3.2 \\
\hline bifacial scraper & - & - & - & 1 & - & 1 & 3.2 \\
\hline end scraper & - & - & - & - & 1 & 1 & 3.2 \\
\hline side scraper & - & 1 & - & - & 4 & 5 & 16.1 \\
\hline end/side scraper & - & - & - & - & 1 & 1 & 3.2 \\
\hline drill & - & - & - & - & 1 & 1 & 3.2 \\
\hline Totals & 3 & 2 & - & 3 & 23 & 31 & 100.0 \\
\hline
\end{tabular}

1=local quartzite; $2=$ petrified wood; $3=$ local chert; 4=novaculite; 5 -non-local chert

The use of non-local lithic raw materials is predominant in the Lizzie Hill flake tools, particularly when compared to the frequency of non-local lithic raw materials in the dart points and arrow points: $83.9 \%$ of the flake tools are made from non-local novaculite and non-local cherts (Ouachita Mountains and Central Texas source areas). Local raw materials used include quartzite and petrified wood. The one drill, $87.5 \%$ of the scrapers, and $82 \%$ of the unilateral/bilateral flake tools are on non-local lithic raw materials.

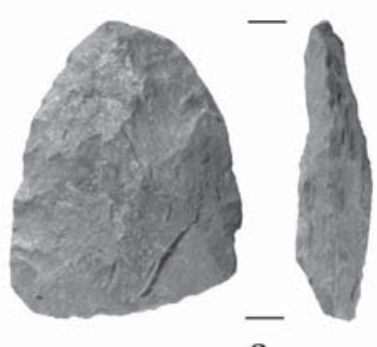

a
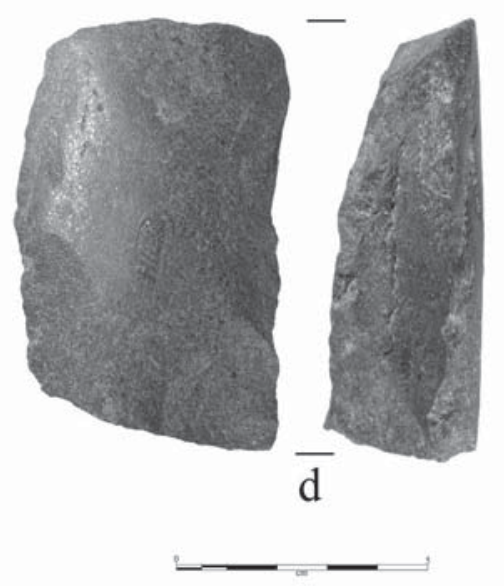

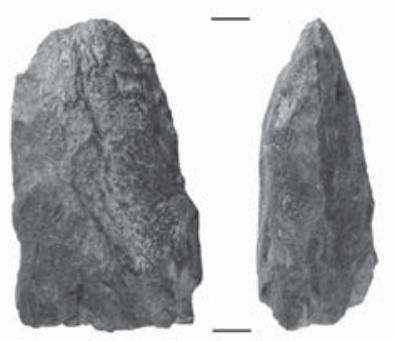

$\mathrm{b}$

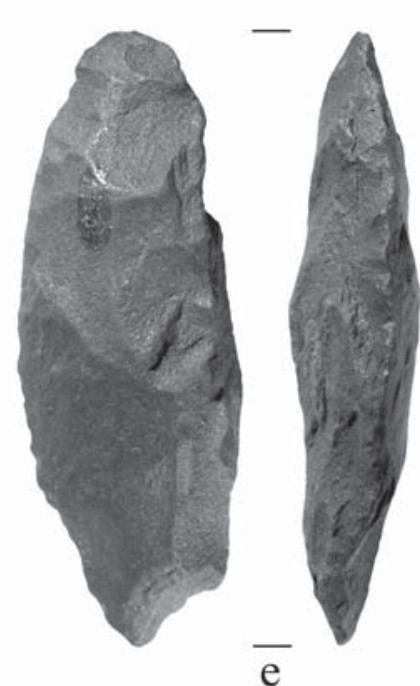

Figure 16. Gouges and chipped hematite biface from the Lizzie Hill site: a-d, gouges; e, large ferruginous sandstone biface preform. 

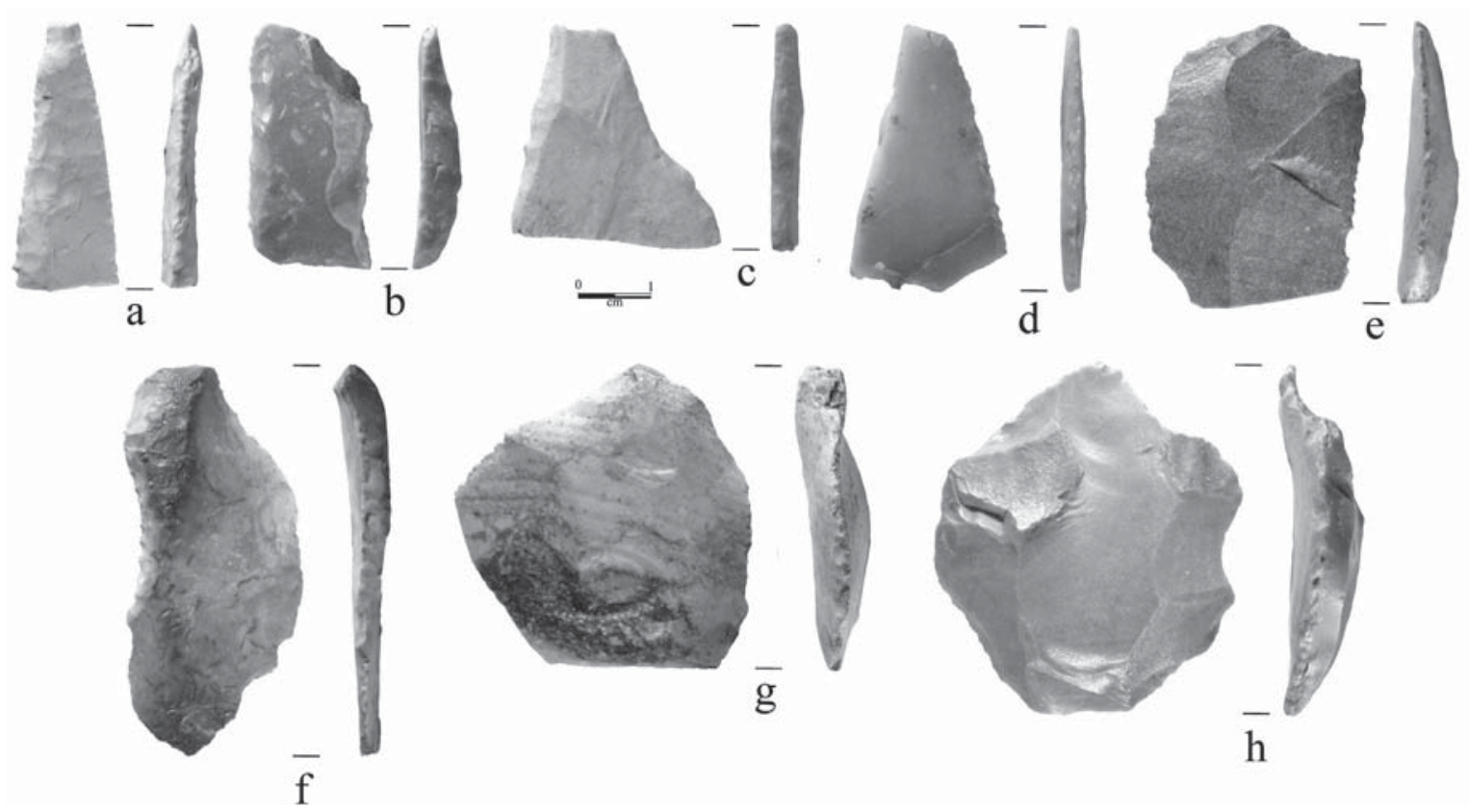

Figure 17. Flake tools: a, drill; b, end-side scraper; c, side scraper; d, unilateral flake tool; e, bilateral flake tool; f, unilateral flake tool; g, unilateral flake tool; h, unilateral flake tool.
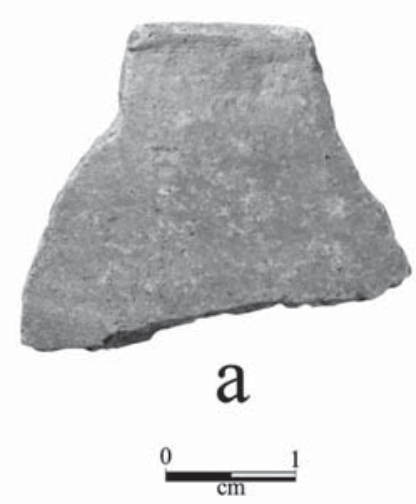

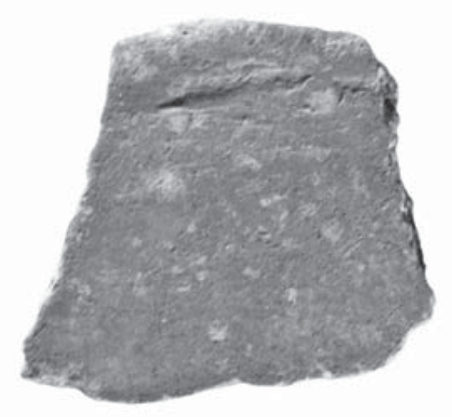

b
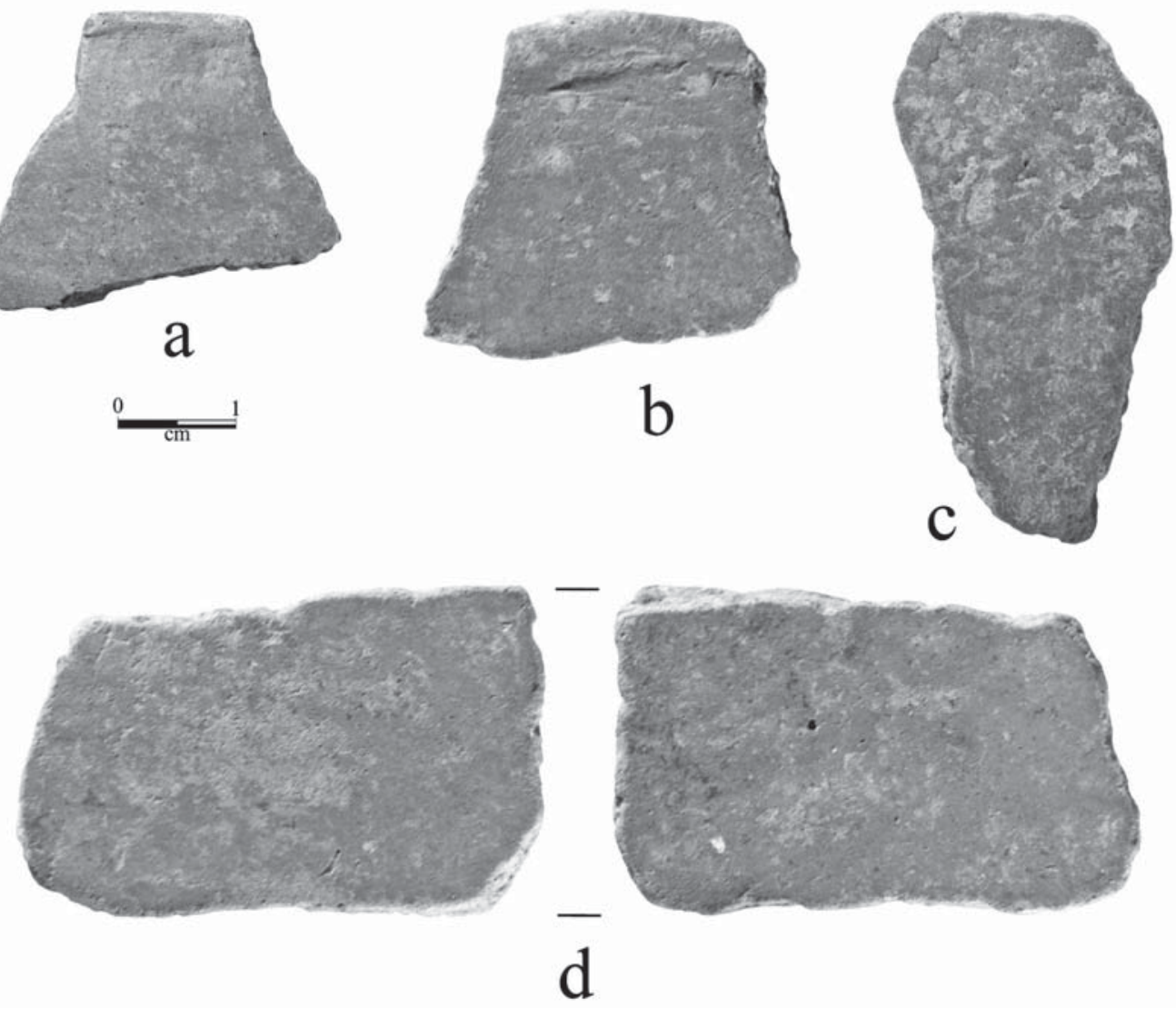

Figure 18. Side Scrapers from the Lizzie Hill site. 
Cores

The 40 cores from the Lizzie Hill site (Table 6) reflect the reduction of primarily pebble-sized pieces of local lithic raw materials gathered from stream gravels; the cores have a smooth, stream-rolled cortex. More than $52 \%$ of the cores are bifacial cores with bifacial flake removals in various directions on the cores (Figure 19b, e). Another $22.5 \%$ of the cores are pebbles that have had a series of flakes removed from either one direction from a usable platform (Figure 19a), or had flakes removed from various sides of the piece (Figure 19c-d).

Table 6. Cores from the Horton site.

\begin{tabular}{lccccccc}
\hline Core type & \multicolumn{7}{c}{ Lithic Raw Material } \\
& 1 & 2 & 3 & 4 & 5 & $\%$ & $\mathrm{~N}$ \\
\hline Bifacial core & 19 & - & 2 & - & - & 70.0 & 21 \\
Multiple platform & 4 & - & - & 1 & 1 & 15.0 & 6 \\
Single platform & 1 & 2 & - & - & - & 7.5 & 3 \\
Tested pebble & 7 & 2 & - & - & - & 22.5 & 9 \\
Tested cobble & 1 & - & - & - & - & 2.5 & 1 \\
\hline Totals & 32 & 4 & 2 & 1 & 1 & 100.0 & 40 \\
\hline
\end{tabular}

1=local quartzite; $2=$ =etrified wood; $3=$ local chert; 4=novaculite; 5-non-local chert

Only two of the cores (5\%), both multiple platform cores, are on non-local lithic raw materials. The other $95 \%$ are on local lithic raw materials, primarily quartzite (80\%) (see Table 6).

\section{Hematite Tools}

A chipped and polished (on one surface) hematite axe fragment is in the collection from the Lizzie Hill site (Figure 20). There are also six pieces to a possible second hematite axe or celt fragment. Both tools are likely from either Middle to Late Archaic period use of the site area (see Turner 2006).

\section{Lithic Debris}

Turner collected only a few pieces of lithic debris from the site, including pieces of quartzite $(n=5)$, petrified wood $(n=2)$, non-local cherts $(n=5$, gray and black colors), and gray novaculite $(n=2)$.

\section{Ground stone tools}

The ground stone tools from the Lizzie Hill site include tools for pounding, pulverizing, and grinding plant foods, including grinding slabs/grinding slab fragments $(n=5)$; manos, with two grinding surfaces $(n=3)$; mano/pitted stone with grinding and pitted areas on both surfaces $(n=3)$; pitted stone, one surface $(n=1)$, and pestle $(n=1)$. There also is a quartzite grooved cobble, perhaps a net weight. The other ground stone tools are also made from local lithic raw materials: quartzite $(n=6)$ and ferruginous sandstone $(n=7)$.

\section{Red Ochre}

There are four pieces of red ochre in the Lizzie Hill site collection, all with polished, smoothed, or abraded surfaces. These were likely sources of red pigment. 

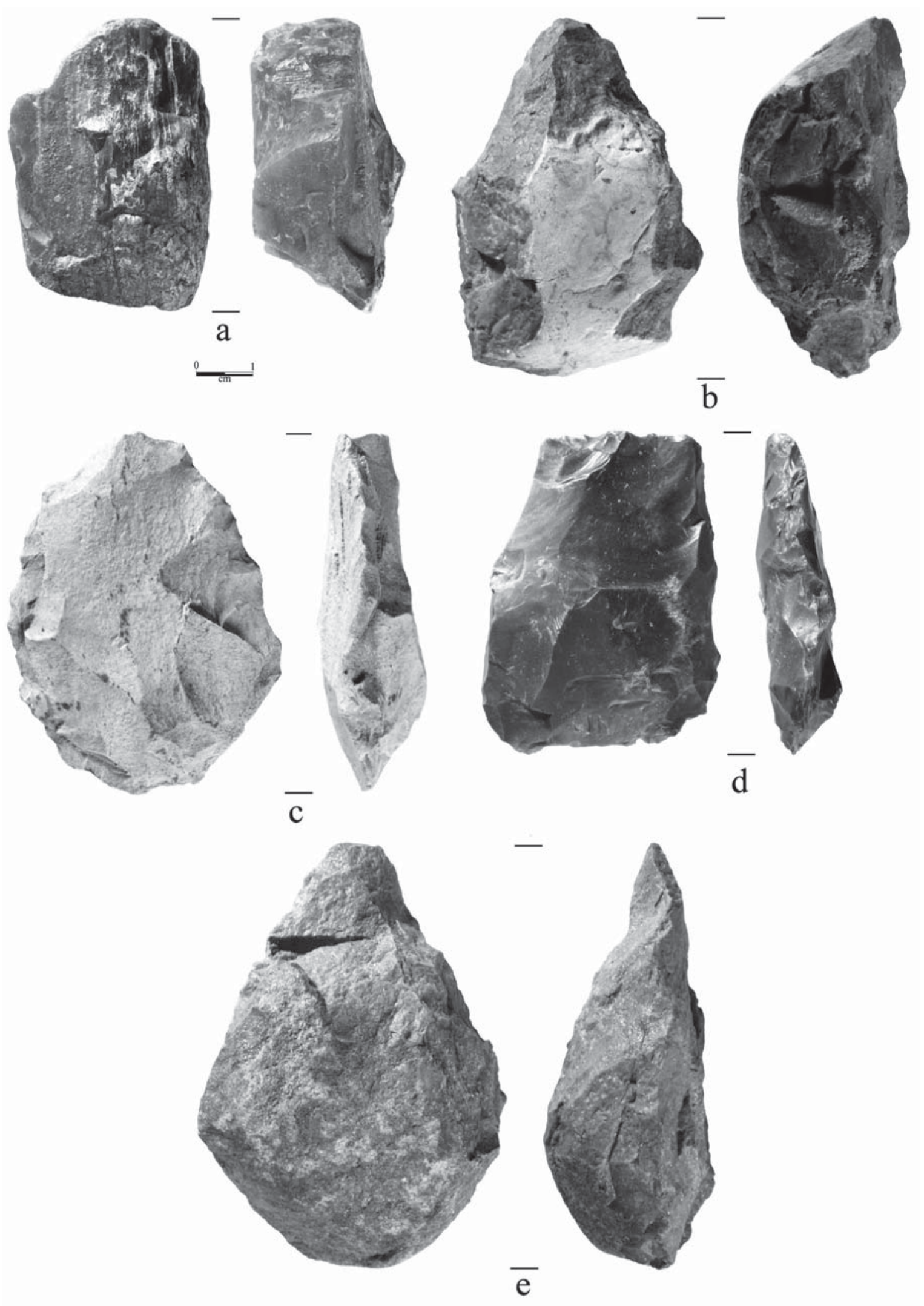

Figure 19. Cores from the Lizzie Hill site: a, single platform; b, e, bifacial; c-d, multiple platform. 


\section{Historic Artifacts}

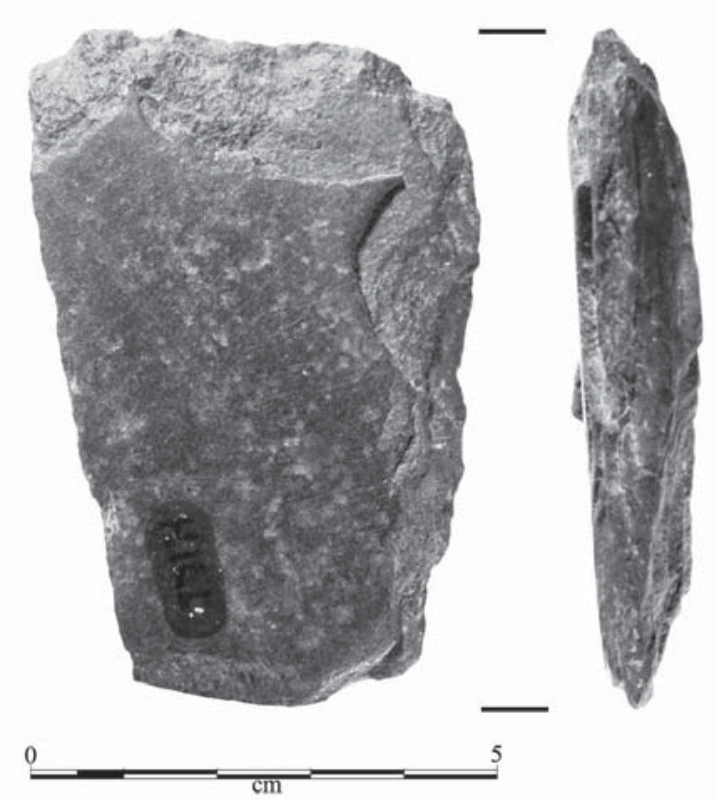

Figure 20. Hematite axe fragment from the Lizzie Hill site.
The few historic artifacts in the collection consist of one lead ball, three lead bullets, and piece of blue (medicinal) bottle glass.

\section{SUMMARY AND CONCLUSIONS}

The Lizzie Hill site (41CP494) is an extensive prehistoric site on a tributary to Walkers Creek in the Big Cypress Creek basin, with large assemblages of chipped and ground stone tools. Also in the Robert L. Turner, Jr. surface collections from the site is a small assemblage of plain and decorated ceramic sherds; the few decorated sherds in the collection suggests the site saw limited use by Caddo peoples sometime after ca. A.D. 1250.

The stone tools from the Lizzie Hill site comprise evidence of aboriginal use from as early as the late Paleoindian period (ca. 10,500 years ago) to ancestral Caddo times after ca. A.D. 800. However, the most extensive use of the site clearly took place during the Late Archaic (ca. 5000-2500 years B.P.) and Wood-

land (ca. 2500-1200 years B.P.) periods, particularly the latter period, at least as indicated by the proportions of typologically identifiable dart points of known age (cf. Turner et al. 2011). The principal dart point types in the assemblage are Yarbrough and Gary.

The abundant numbers of broken bifaces and cores of local lithic raw materials (i.e., coarse- and finegrained quartzite, petrified wood, and earth-toned cherts) at the Lizzie Hill site is indicative of considerable tool manufacturing activities at the site employing these local materials, as well as the discard of broken bifaces and exhausted pebble cores. Only $5 \%$ of the cores and $8 \%$ of the bifaces are on non-local lithic raw materials; the occurrence of non-local lithics in these artifact classes suggest some importation or procurement of non-local lithics in raw form, as well as in completed form, with tools being resharpened as needed to extend their use-lives.

Late Paleoindian and Middle Archaic dart points tend to be of non-local lithic raw materials, as are flake tools and scrapers during all periods, and it is possible that the aboriginal groups that used and discarded these points at the Lizzie Hill site had extensive foraging ranges, and directly obtained these materials during foraging in the Red River basin, the Ouachita Mountains, and in Central Texas. By the Late Archaic, the use of non-local lithic raw materials had diminished considerably, and only about $12 \%$ of the dart points in this period are made from non-local raw materials, particularly cherts. These points were most likely obtained through trade/exchange practices rather than through direct procurement. By the Woodland period, the acquisition and use of non-local lithics had diminished even farther (to 7\%), but most of the dart points then were made from novaculite, suggesting a change in the direction of trade/exchange between Woodland period populations in the Trans-Mississippi South and the East Texas Pineywoods and Post Oak Savanna.

\section{ACKNOWLEDGMENTS}

Thanks to Lance Trask for his preparation of the many artifact figures in this article. 


\section{REFERENCES CITED}

Johnson, L., Jr.

1962 The Yarbrough and Miller Sites of Northeastern Texas, With a Preliminary Definition of the La Harpe Aspect. Bulletin of the Texas Archeological Society 32:141-284.

Schambach, F. F.

1982 An Outline of Fourche Maline Culture in Southwest Arkansas. In Arkansas Archeology in Review, edited by N. L. Trubowitz and M. D. Jeter, pp. 132-197. Research Series No. 15. Arkansas Archeological Survey, Fayetteville.

1998 Pre-Caddoan Cultures of the Trans-Mississippi South. Research Series 53. Arkansas Archeological Survey, Fayetteville.

Trubitt, M. B.

2009 Investigating Middle Archaic at the Jones Mill Site. The Arkansas Archeologist 48:71-84.

Turner, E. S., T. R. Hester, and R. L. McReynolds

2011 Stone Artifacts of Texas Indians. $3^{\text {rd }}$ Edition. Taylor Trade Publishing, Lanham, Maryland.

Turner, R. L.

2006 Hematite Axes of Northeast Texas. Bulletin of the Texas Archeological Society 77:1-32. 